\title{
New insights in the biogeographical distributions of two Spionidae (Annelida) from the NE Atlantic and Mediterranean French coasts
}

\author{
JÉRÔME JOURDE ${ }^{1,5^{*}}$, NICOLAS LAVESQUE ${ }^{2,7}$, CÉLINE LABRUNE $^{3,10}$, JEAN-MICHEL AMOUR- \\ OUX $^{3,12}$, PAULO BONIFÁCIO ${ }^{3,11}$, SUZIE HUMBERT ${ }^{2,8}$, BASTIEN LAMARQUE ${ }^{2,9}$, PIERRE-GUY \\ SAURIAU ${ }^{1,6} \&$ KARIN MEIßNER ${ }^{4,13}$ \\ ${ }^{1}$ La Rochelle Université, CNRS, UMR 7266 LIENSs, 2 rue Olympe de Gouges 17000 La Rochelle, France \\ ${ }^{2}$ Université de Bordeaux, CNRS, UMR 5805 EPOC, Station Marine d'Arcachon, 2 rue du Professeur Jolyet, 33120 Arcachon, France \\ ${ }^{3}$ Sorbonne Université, CNRS, UMR LECOB 8222, Laboratoire d'Ecogéochimie des Environnements Benthiques, Observatoire \\ Océanologique de Banyuls, Avenue Pierre Fabre, 66650 Banyuls-sur-Mer, France \\ ${ }^{4}$ Senckenberg Forschungsinstitute und Naturmuseen (SFN), Deutsches Zentrum für Marine Biodiversitätsforschung, Biozentrum \\ Grindel, Martin-Luther-King-Platz 3, D-20146 Hamburg, Germany \\ 5 ¡"jjourde@univ-lr.fr, @ https://orcid.org/0000-0001-7260-8419 \\ 6" pierre-guy.sauriau@univ-lr.fr, @ichttps://orcid.org/0000-0002-5360-8728 \\ 7 "nicolas.lavesque@u-bordeaux.fr, @ https://orcid.org/0000-0001-5701-2393 \\ ${ }^{8} \equiv "$ suzie.humbert@u-bordeaux.fr, @ ittps://orcid.org/0000-0003-4254-3567 \\ 9 " bastien.lamarque@u-bordeaux.fr, @ https://orcid.org/0000-0002-1418-9049 \\ ${ }_{10} \equiv$ labrune@obs-banyuls.fr, ○https://orcid.org/0000-0002-8470-347X \\ ${ }^{11}$ ”"bonif@me.com, (1) https://orcid.org/0000-0001-9036-7145 \\ 12 ”- phaxas.amouroux@gmail.com, @ https://orcid.org/0000-0002-3020-2266 \\ ${ }^{13} \equiv=$ karin.meissner@senckenberg.de, @ 1 https://orcid.org/0000-0002-1823-9891 \\ *Corresponding author
}

\begin{abstract}
We report the first occurrences of Spiophanes afer Meißner, 2005 and Prionospio cristaventralis Delgado-Blas, DíazDíaz \& Viéitez, 2018 from French marine waters (from the southern part of the Bay of Biscay in NE Atlantic, and the Gulf of Lion in the Mediterranean Sea). Morphological characters of S. afer include the presence of an occipital antenna, dorsal ciliated organs extending to chaetigers 13-15, neuropodial hooks from chaetiger 15, ventrolateral intersegmental pouches from chaetigers 14-15, chaetal spreaders of " $2+3$ type", and conspicuous dark brown pigmentation on parapodia of chaetigers 9-13. Prionospio cristaventralis has four pairs of branchiae ( $1^{\text {st }}$ and $4^{\text {th }}$ pinnate, $2^{\text {nd }}$ and $3^{\text {rd }}$ apinnate), ventral crests from chaetigers 11-12, high dorsal crests on chaetigers 10-11, and very large notopodial prechaetal lamellae on anterior chaetigers. Both records represent northern extensions of their known distributions. However, the presence of $S$. afer on French coasts may have been overlooked for several decades. The validity of the recently proposed Spiophanes adriaticus is questioned.
\end{abstract}

Key words: polychaetes, Spiophanes adriaticus, Spiophanes afer, Prionospio cristaventralis, Bay of Biscay, Gulf of Lion

\section{Introduction}

Spionidae (Annelida: Polychaeta) is a large taxon currently including 38 genera and 590 valid species worldwide (Read \& Fauchald 2019). They inhabit both fresh and marine waters with silty, sandy and rocky bottoms, from shallow to deep waters, and from clean to polluted environments (Blake et al. 2017, Martinez \& Adarraga 2019). In the Bay of Biscay and Mediterranean waters, new species are regularly recorded as progress is made in the systematics and biogeography of Spionidae (Aguirrezabalaga \& Ceberio 2005; Meißner 2005; Çinar et al. 2015; Lavesque et al. 2015; Radashevsky et al. 2016; Surugiu 2016; Bogantes et al. 2018; Delgado-Blas et al. 2018; Delgado-Blas et al. 2019; Radashevsky et al. 2019).

Among spionids, species of Spiophanes and Prionospio are regularly found in samples from French coastal 
marine waters. The genera Prionospio Malmgren, 1867 and Spiophanes Grube, 1860 comprise 104 and 31 species, respectively, of which nine and five have been reported from French waters (RESOMAR 2019; OBIS 2019): P. caspersi Laubier, 1962, P. cirrifera Wirén, 1883, P. dubia Day, 1961, P. elhersi Fauvel, 1928, P. fallax Söderström, 1920, P. multibranchiata Berkeley, 1927, P. saldanha Day, 1961, P. sexoculata Augener, 1918, P. steenstrupi Malmgren, 1867, and S. bombyx (Claparède, 1870), S. kroyeri Grube, 1860, S. duplex (Chamberlin, 1919), S. reyssi Laubier, 1964 and S. viriosus Meißner \& Hutchings, 2003. However, in recent surveys along the French coast of the Bay of Biscay two additional spionid species hitherto not reported from the French Atlantic were collected: Prionospio cristaventralis Delgado-Blas, Díaz-Díaz \& Viéitez, 2018 and Spiophanes afer Meißner, 2005. Prionospio cristaventralis was originally described from the Spanish Atlantic coast of the Bay of Biscay (Delgado-Blas et al. 2018), while S. afer was described from waters adjacent to the African continent (Mediterranean Sea and South Atlantic Ocean) with the type locality in the Spanish Mediterranean Sea between Cape San Antonio and the Port of Valencia (Meißner, 2005) (Fig. 1). The latter had never been recorded in Atlantic waters further north than on the continental shelf off Aveiro, Portugal (Gil 2011; Ravara \& Moreira 2013, Delgado-Blas et al. 2019). Furthermore, NE Atlantic reports of S. afer are very rare, with records in the $1^{\text {st }}$ and $2^{\text {nd }}$ part of the SEPLAT 7 campaigns in 1981 and 1983 (Gil 2011), and in 1995 and 1996 (Ravara \& Moreira 2013). Prior to our study, S. afer had also not been reported from the French Mediterranean coast.

In this study we analyse the geographical distributions of both species, and provide complementary morphological information.

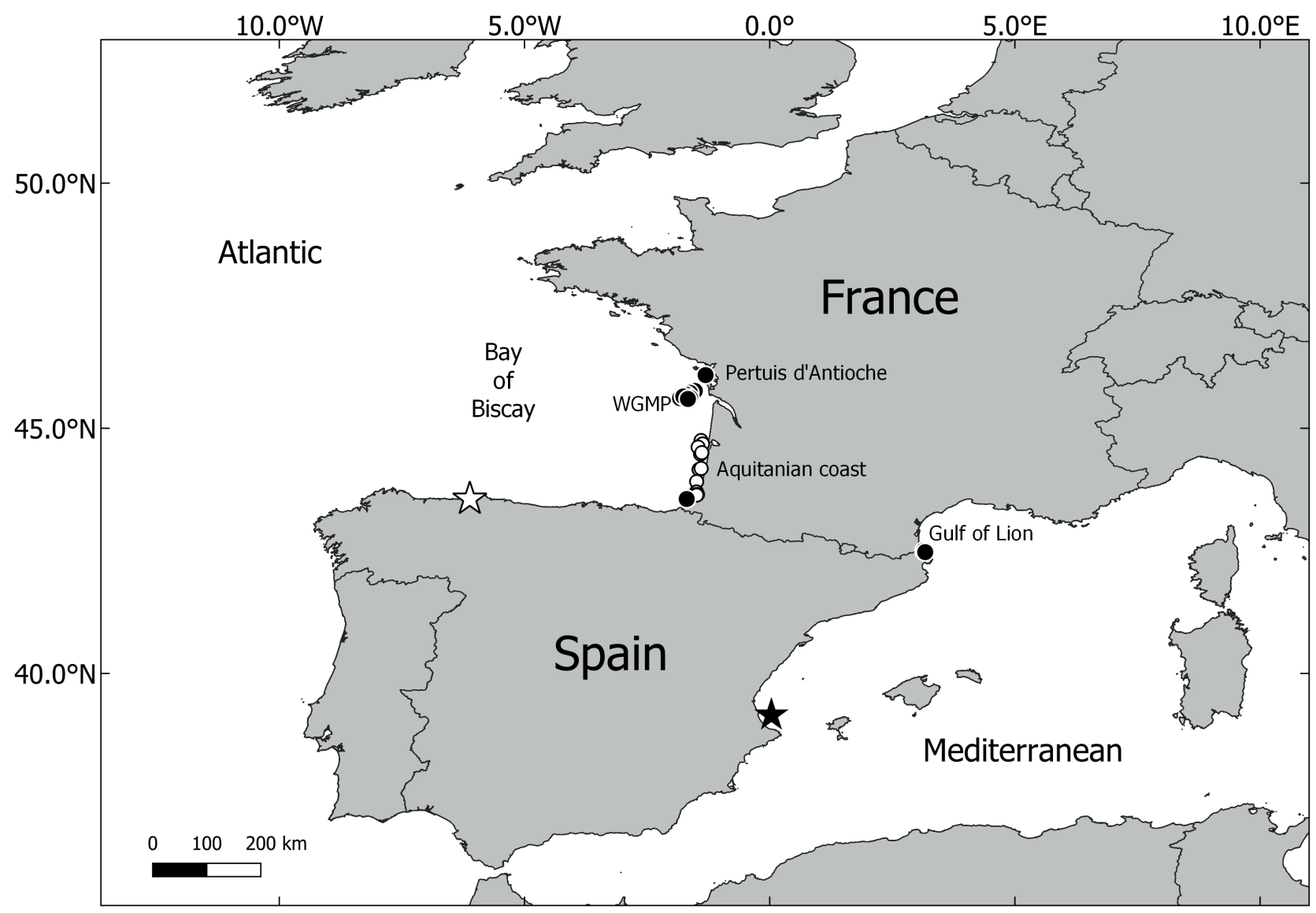

FIGURE 1. Spiophanes afer (black dots) and Prionospio cristaventralis (white dots) distributions along French coasts (WGMP: West Gironde Mud Patch). Black and white stars indicate the respective type localities.

\section{Material and methods}

Samples examined in the course of the present study were collected during several benthic ecology projects. OBIONE is an annual monitoring project implemented since 2011 on a subtidal SOMLIT (i.e., French Coastal 
Monitoring Network, Liénart et al. 2018) station located between Ré and Oléron islands (Pertuis d'Antioche) at $40 \mathrm{~m}$ water depth on muddy sands (Fig. 1, Table 1). The JERICO project was implemented from 2016 to 2018 at the West Gironde Mud Patch (WGMP), a $420 \mathrm{~km}^{2}$ clay-silt sedimentary area, $25 \mathrm{~km}$ off the mouth of the Gironde Estuary in the Bay of Biscay (Deflandre 2016, Massé et al. 2016) (Fig. 1). The RTE (French transmission system operator: https://www.rte-france.com/en) is a biosedimentary study carried out in May 2018 on sandy sediments, from 20 to $120 \mathrm{~m}$ water depth, along the Aquitanian coast (southern Bay of Biscay). The REDIT, RNMCB and IBIS projects were implemented between 2009 and 2018 in the Gulf of Lion (French Catalan coast, NW Mediterranean).

TABLE 1. Sampling stations from where Spiophanes afer (S.a.) and Prionospio cristaventralis (P.c.) were collected. Coordinates are in WGS84. (HMS: Heterogeneous muddy sand).

\begin{tabular}{|c|c|c|c|c|c|c|c|c|}
\hline & Station & $\mathbf{Y}(\mathbf{N})$ & $X(E)$ & Species & Years & Abundances & Depth (m) & Sediment \\
\hline \multirow{5}{*}{$\begin{array}{l}\text { Gulf of } \\
\text { Lion }\end{array}$} & 26 & $42.4987^{\circ}$ & $3.1465^{\circ}$ & S.a. & 2017 & 2 & 31 & Sandy Mud \\
\hline & 183 & $42.5083^{\circ}$ & $3.1518^{\circ}$ & S. $a$ & 2018 & 2 & 40 & Sandy Mud \\
\hline & Em_30 & $42.4839^{\circ}$ & $3.1467^{\circ}$ & S.a. & 2017 & 1 & 31 & HMS \\
\hline & Y30 & $42.5053^{\circ}$ & $3.1452^{\circ}$ & S.a. & 2010 & 1 & 30 & HMS \\
\hline & $\mathrm{Z} 40$ & $42.4738^{\circ}$ & $3.1699^{\circ}$ & S.a. & 2010 & 3 & 40 & Sandy Mud \\
\hline \multirow[t]{4}{*}{$\begin{array}{c}\text { Pertuis } \\
\text { d'Antioche }\end{array}$} & SOMLIT & $46.0842^{\circ}$ & $-1.3083^{\circ}$ & S.a. & 2011-18 & 5 & 40 & Muddy Sand \\
\hline & 1 & $45.7617^{\circ}$ & $-1.5278^{\circ}$ & S.a. & 2016-18 & 1 & 40 & Mud \\
\hline & 2 & $45.7244^{\circ}$ & $-1.6292^{\circ}$ & S.a. & 2016-18 & 1 & 47 & Mud \\
\hline & 3 & $45.6825^{\circ}$ & $-1.6917^{\circ}$ & S.a. & 2016-18 & 1 & 56 & Mud \\
\hline \multirow[t]{11}{*}{ WGMP } & 4 & $45.6139^{\circ}$ & $-1.8297^{\circ}$ & S.a. & 2016-18 & 1 & 69 & Mud \\
\hline & 7 & $45.6208^{\circ}$ & $-1.6253^{\circ}$ & S.a. & 2016 & 1 & 53 & Mud \\
\hline & 8 & $45.6483^{\circ}$ & $-1.7633^{\circ}$ & S.a. & 2016-18 & 1 & 61 & Mud \\
\hline & 9 & $45.5981^{\circ}$ & $-1.6689^{\circ}$ & S.a. & 2016 & 1 & 55 & Mud \\
\hline & P40 & $43.5572^{\circ}$ & $-1.6936^{\circ}$ & S.a. & 2018 & 1 & 112 & Fine Sand \\
\hline & P07 & $44.7500^{\circ}$ & $-1.4014^{\circ}$ & P.c. & 2018 & 1 & 35 & Medium Sand \\
\hline & P09 & $44.6433^{\circ}$ & $-1.4192^{\circ}$ & P.c. & 2018 & 5 & 47 & Medium Sand \\
\hline & P10 & $44.5981^{\circ}$ & $-1.4272^{\circ}$ & P.c. & 2018 & 1 & 55 & Fine Sand \\
\hline & $\mathrm{P} 12$ & $44.4736^{\circ}$ & $-1.4103^{\circ}$ & P.c. & 2018 & 1 & 51 & Coarse Sand \\
\hline & $\mathrm{P} 13$ & $44.6806^{\circ}$ & $-1.3708^{\circ}$ & P.c. & 2018 & 1 & 35 & Medium Sand \\
\hline & P14 & $44.6156^{\circ}$ & $-1.4608^{\circ}$ & P.c. & 2018 & 3 & 59 & Medium Sand \\
\hline \multirow{8}{*}{$\begin{array}{l}\text { Aquitanian } \\
\text { coast }\end{array}$} & P15 & $44.5033^{\circ}$ & $-1.3856^{\circ}$ & P.c. & 2018 & 1 & 46 & Coarse Sand \\
\hline & P19 & $44.1597^{\circ}$ & $-1.4414^{\circ}$ & P.c. & 2018 & 1 & 47 & Fine Sand \\
\hline & $\mathrm{P} 21$ & $44.1808^{\circ}$ & $-1.3994^{\circ}$ & P.c. & 2018 & 3 & 39 & Fine Sand \\
\hline & $\mathrm{P} 23$ & $43.9119^{\circ}$ & $-1.4911^{\circ}$ & P.c. & 2018 & 1 & 48 & Fine Sand \\
\hline & $\mathrm{P} 25$ & $43.7014^{\circ}$ & $-1.4942^{\circ}$ & P.c. & 2018 & 1 & 40 & Fine Sand \\
\hline & P29 & $43.6494^{\circ}$ & $-1.4733^{\circ}$ & P.c. & 2018 & 1 & 19 & Fine Sand \\
\hline & P30 & $43.6458^{\circ}$ & $-1.5183^{\circ}$ & P.c. & 2018 & 1 & 46 & Fine Sand \\
\hline & P33 & $43.6369^{\circ}$ & $-1.4914^{\circ}$ & P.c. & 2018 & 1 & 29 & Fine Sand \\
\hline
\end{tabular}

Sampling gear included a Smith-McIntyre grab (Pertuis d'Antioche), a Hamon grab (WGMP and Aquitanian coast), and a van Veen grab (Gulf of Lion), sampling $0.1 \mathrm{~m}^{2}$ (Pertuis d'Antioche, Gulf of Lion) or $0.25 \mathrm{~m}^{2}$ (WGMP and Aquitanian coast). All samples were washed through a $1 \mathrm{~mm}$-mesh sieve and preserved with a $10 \%$ formalin/marine water solution on board. They were subsequently washed again through a 0.5 mm-mesh sieve. Extracted macrofauna was preserved in $70 \%$ ethanol. For identification a Leica M205C stereomicroscope equipped with a Leica MC190 HD camera and an Olympus BH2 light microscope were 
used. Following Meißner (2005) we define body width in Spiophanes as the distance between the distalmost points of both parapodial rami from chaetiger 4 (chaetae and postchaetal lobes disregarded) seen from above. Some specimens were stained with a dark solution of methyl green in ethanol. Specimens were dipped into the solution for five minutes, allowed to destain in ethanol for a few seconds, then observed in water. Specimens of $P$. cristaventralis used for scanning electron microscopy (SEM) were critical point dried, gold coated, then examined and photographed with a Hitachi TM3030. Part of the studied material is deposited at the Muséum National d'Histoire Naturelle, Paris (MNHN) and the Senckenberg Museum, Frankfurt (SMF).

\section{Results}

This study focused on the examination of twenty-two specimens of both $S$. afer and P. cristaventralis (Table 1). While, $S$. afer was collected from all localities, $P$. cristaventralis was sampled only in the Aquitanian coast. Further descriptions of both species are provided in the systematic account section. In addition, among the nine Spiophanes specimens from the French Mediterranean coast off Banyuls-sur-Mer, four sampled in 2010 and previously identified as Spiophanes viriosus Meißner \& Hutchings, 2003 were re-examined and eventually attributed to $S$. afer.

\section{Systematic account}

\section{Spionidae Grube, 1850}

\section{Spiophanes Grube, 1860}

\section{Spiophanes afer Meißner, 2005}

(Fig. 2)

Type locality. Between Cape San Antonio and Port of Valencia, Mediterranean Spanish coast (Fig.1).

Material examined. Non-type material: NE Atlantic Ocean, Bay of Biscay, Pertuis d'Antioche, 40 m, 3 specimens (September 2011, MNHN-IA- PNT 100; 2016, MNHN-IA- PNT 101 and 2018, SMF 28059), West Gironde (WGMP) and Aquitanian coast, 40-69 m, 3 specimens (2016, MNHN-IA- PNT 110; March, MNHNIA- PNT 111; and August 2017, MNHN-IA- PNT 112); Mediterranean Sea, off Banyuls-sur-Mer, 30-40 m, 9 specimens (2010, MNHN-IA- PNT 106, MNHN-IA- PNT 107, MNHN-IA- PNT 108, MNHN-IA- PNT 109; 2017, MNHN-IA- PNT 102, MNHN-IA- PNT 103, MNHN-IA- PNT 105; and 2018 SMF 28060, MNHN-IAPNT 104).

Description of material collected in the course of the present study. All specimens incomplete, 6.4-30 $\mathrm{mm}$ long for 22-60 chaetigers, $0.7-1.2 \mathrm{~mm}$ wide. Colour in alcohol pale white (West Gironde and Pertuis d'Antioche) to grey/brown (Banyuls sur Mer), except for dark pigmentation on parapodia of chaetigers 9-13 (Fig. 2A). Prostomium broad anteriorly, bell-shaped, with blunt, short anterolateral projections (Fig. 2A). Palps lost. Occipital antenna present. Up to four eye spots, rarely absent (see remarks). Dorsal ciliated organs as two straight ciliated bands along dorsum, extending usually to chaetigers 13-15 (Fig. 2A; see remarks).

Chaetal spreader of " $2+3$ type" with undulate glandular opening well developed in chaetigers 5-7 (Fig. 2B); opening of glandular organ absent on chaetiger 8 , as lateral vertical slits on chaetigers 9-14. Ventrolateral intersegmental pouches present from chaetigers 14-15, fully developed from chaetigers 15-16. Dorsal ciliated crests distinct from chaetigers 17-19, moderately to well developed.

Neuropodium of chaetiger 1 usually with one stout, crook-like chaeta (see remarks) and numerous simple capillaries; notochaetae much longer than neurochaetae, almost twice as long as those of chaetiger 2 (Fig. 2C). Capillaries on chaetiger 2 twice as long as on chaetigers 3-4. From chaetiger 15, with quadridentate non-hooded neuropodial hooks, initially numbering 6-8 (4-7 in Mediterranean specimens). Bacillary chaetae as thin hirsute bristles with brush-like tip, sometimes exposed on chaetigers 5-7. Ventral sabre chaetae from chaetiger 4. 

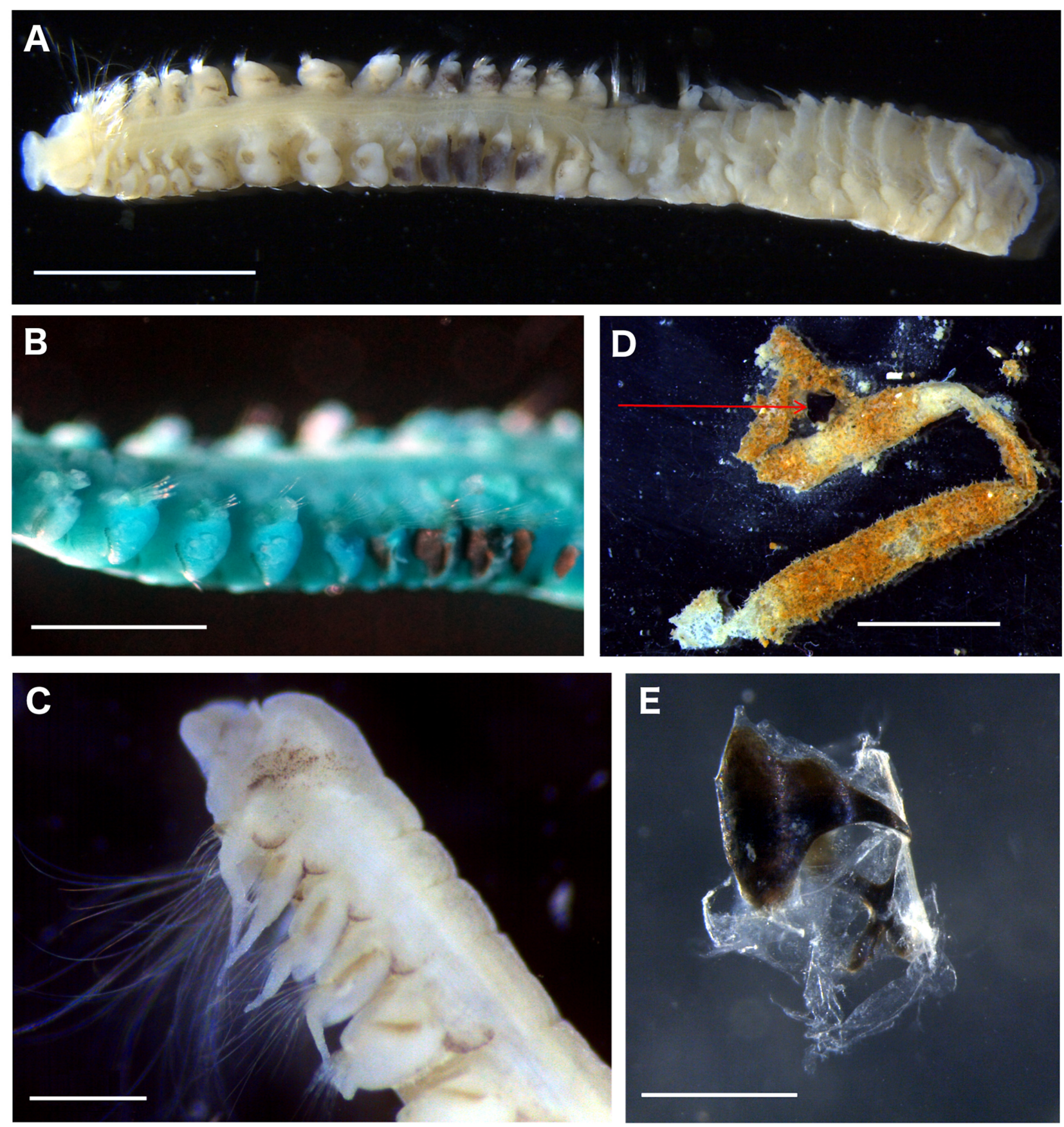

FIGURE 2. Spiophanes afer, MNHN-IA-PNT 101 (A, C, D, E), MNHN-IA-PNT 100 (B). A. Anterior fragment, dorsal view, B. Segments 4-13, lateral view, note chaetal spreader of " $2+3$ type" in chaetigers 5, 6 \& 7 and dark brown pigment in chaetigers 9-13; blue colour due to staining with methyl green. C. Anterior region, ventro-lateral view, D. Tube, chitinous ring arrowed, E. Detail of chitinous ring. Scales: $A=2 \mathrm{~mm}, \mathrm{~B}, \mathrm{E}=1 \mathrm{~mm}, \mathrm{C}=500 \mu \mathrm{m}, \mathrm{D}=5 \mathrm{~mm}$.

\section{Pygidium unknown.}

Tube. Tube coated with sand (Fig. 2D), sometimes with up to two dark, complex chitinous ring-like structures inside, divided into two parts linked by a transparent membrane, the bigger part nail-shaped with two lateral wings, the second x-shaped (Fig. 2D, E).

Pigmentation. These observations are based on specimens fixed in formalin solution then preserved in $70 \%$ ethanol. Dark pigment on chaetigers 9-13 (Fig. 2A, B), most intense anterior to the parapodia and around the opening of the glandular organ, entirely encompassing parapodium on chaetigers 10-11; pigmented area smaller on chaetiger 9 compared to 10-13. Among our specimens, slight variations were observed: in specimens from 
the Pertuis Charentais, dark pigmentation of chaetigers 9-13 was more intense than in other localities; West Gironde and Aquitanian specimens were almost completely unpigmented (apart from chaetigers 9-13), while those of Pertuis d'Antioche showed variable patterns of blots of light brown pigment on anterior segments including the peristomium (Fig. 2C).

Methyl green staining pattern. No particular pattern.

Remarks. To date, three valid species of Spiophanes are known, presenting the following combination of morphological characters: presence of an occipital antenna, glandular organs in chaetigers 5-7 with " $2+3$ " chaetal spreader type, and obvious dark pigment on chaetigers 9-13. These species are $S$. afer from seas around Africa, S. kimballi Meißner, 2005 from off California, USA, and S. viriosus Meißner \& Hutchings, 2003 from Eastern Australia. The species are easily distinguished by the extension of the dorsal ciliated organs which reach chaetigers 13-15 in S. afer, chaetigers 17-18 in S. viriosus, and chaetigers 11-13 in S. kimballi (Meißner, 2005), this latter exhibiting a distinctive shape. Also, in S. afer, ventrolateral intersegmental pouches begin from chaetiger 14 and are first fully developed between chaetigers 15-16. In contrast, they are fully developed from between chaetigers 14-15 in S. viriosus, whereas in S. kimballi pouches were only observed in reproductive specimens (Meißner, 2005). In addition, to our knowledge, both $S$. kimballi and $S$. viriosus have never been recorded far from their original distribution areas.

Recently a fourth species presenting the same above-mentioned character combination has been described from the Adriatic Sea: Spiophanes adriaticus D'Alessandro, Castriota, Maggio, Nasi, Carletti, Auriemma \& Romeo 2019 (D'Alessandro et al. 2019). However, we are not entirely convinced that $S$. adriaticus is a new species. Based on the type of chaetal spreader (" $2+3$ " with undulate opening in chaetigers 5-7), D' Alessandro et al. (2019) acknowledged morphological similarities between S. adriaticus and S. afer and discussed characters in disagreement between the two species. Accordingly, the first morphological difference is the presence of eyes in adult specimens in $S$. adriaticus whereas they were reported to be only rarely present in juvenile S. afer and absent in adult specimens. It has to be considered that the description of S. adriaticus is based exclusively on recently collected material preserved in $96 \%$ ethanol whereas the description of $S$. afer was undertaken based on material from museum collections collected decades ago and fixed in formalin. Formalin and ethanol preserve pigmentation in a different way, and pigment is well maintained in freshly preserved ethanol material (see e.g. figure 13 page 229 in Meißner et al. 2014 and page 396 in Meißner \& Götting 2015). A second distinctive morphological feature is the length of the dorsal ciliated organs running to about chaetigers 13-15 in S. afer and to about chaetigers 11-12 in S. adriaticus. However, the illustrations supposedly documenting this in S. adriaticus are difficult to interpret and suggest that dorsal ciliated organs could reach chaetiger 13. The third differential character listed by the authors is the shape of parapodia, without detailing the differences. Based on the illustrations provided, such differences are not obvious to us. A fourth distinction is that dorsal ciliated crests are described as usually distinct from chaetigers 18-19 in S. afer, and from chaetigers 14-17 in S. adriaticus. The crests are usually not well preserved in every specimen and the differentiation between the first presence and their appearance as distinct crest is not clear-cut and might be biased. We do not think that this character is the most reliable but it could of course be an indication of species-level differences. We think the examination of a greater number of specimens from different locations, differently preserved, collected in different seasons, and belonging to different age classes is required before defining stable differential characters. D'Alessandro et al. (2019) presented results of morphological examination of 20 specimens collected at two different locations in the Adriatic Sea, but did not conclusively assess ontogenetic variability of various morphological characters. In any case, we are missing comparative studies of morphologically similar species from the publication by D'Alessandro et al. (2019). Also, the deposition of type material in museum collections is compulsory but official registration numbers were not provided by the authors. D'Alessandro et al. (2019) also retrieved molecular information from their Adriatic specimens but the publication is missing sequence information (e.g. GenBank accession numbers). More importantly, the presented phylogenetic analysis of Spiophanes species undertaken by D'Alessandro et al. (2019) includes only species distantly related to $S$. adriaticus/S. afer (based on our judgement of their morphology), and hence neither supports nor rejects the hypothesis of $S$. adriaticus being a formerly unknown Spiophanes species. Thus, the separation of $S$. afer and S. adriaticus is not well resolved yet, and we reject a formal acceptance of this species and urge the authors to provide registration numbers for type material.

All our specimens are in good agreement with the original description of S. afer and only the presence of eye spots was observed to vary. 
The main variation observed between our specimens consists in differences in the extension of the dorsal ciliary band: Mediterranean individuals have dorsal ciliary bands mainly extending to chaetiger 13 (instead of chaetiger 15 for Pertuis d'Antioche individuals, or intermediate for West Gironde and Aquitania individuals). However, within localities the dorsal ciliary band extension also varied (to chaetigers 9-14 in Banyuls-surMer, to chaetigers 11-14 in West Gironde). Intraindividual variation was also observed on a specimen showing asymmetric bands: one extending to chaetiger 13 and the other to chaetiger 14 (MNHN-IA-PNT 105). Other observed variations were: no eye spot on one specimen (MNHN-IA-PNT 101), three eye spots on two specimens (MNHN-IA-PNT 100 and MNHN-IA-PNT-105), and two crook-like chaetae on chaetiger 1 neuropodium of one specimen (MNHN-IA-PNT 111). Mediterranean individuals are generally darker and initially have 4-7 neuropodial hooks (6-8 in the Atlantic).

As previously noted, the occurrence of eye spots is likely linked to preservation method. The dorsal ciliary band extension and initial number of neuropodial hooks are likely to be linked to the development stage and, consequently, to body size (Meißner 2005). Accordingly, our Mediterranean specimens were smaller, measuring $0.8-1 \mathrm{~mm}$ wide vs. $1-1.2 \mathrm{~mm}$ wide for the Atlantic specimens. However, these characters vary within and among our populations.

The dark chitinous rings found in the tubes of Atlantic specimens have also been reported by D'Alessandro et al. (2019). Following these authors, they could have a support function.

Habitat. From intertidal to depths up to $60 \mathrm{~m}$ (Meißner, 2005). Between 40 and $112 \mathrm{~m}$, usually in muddy sediments, sometimes on fine sand (e.g., on the Aquitanian coast, this study).

Distribution. Mediterranean Sea: off Spain, off Israel, off France (this study); South Atlantic Ocean: off Namibia; North Atlantic Ocean: Bay of Biscay (this study); Indian Ocean: off South Africa;

\section{Prionospio Malmgren, 1867 sensu stricto}

\section{Prionospio cristaventralis Delgado-Blas, Díaz-Díaz \& Viéitez, 2018}

(Fig. 3, 4)

Type locality. Between Cabo Vidio and Cabo de Peñas, Asturias, Spain (Fig. 1).

Material examined. Non-type material: Atlantic, Bay of Biscay, station P21, 39 m, 3 specimens (May 2018, MNHN-IA- PNT 113); Atlantic, Bay of Biscay, station P14, 59 m, 3 specimens (May 2018, MNHNIA- PNT 114), mounted for SEM; SMF 25 327, Atlantic, Bay of Biscay, station P09, 47 m, 5 specimens (May 2018).

Description. Complete specimen, $22.6 \mathrm{~mm}$ long (about 65 chaetigers), $0.9 \mathrm{~mm}$ wide. Pale white in alcohol (Fig. 3A). Prostomium bottle-shaped, broadly rounded (Fig. 3A, D), dorsoventrally flattened on anterior margin (Fig. 4A, C); long, narrow caruncle extending to end of chaetiger 2, sinusoidal at posterior end (Fig. 3D); nuchal organs U-shaped. Two pairs of black subdermal eyes in trapezoidal arrangement; those of anterior pair small round, those on posterior pair large crescent-shaped (Fig. 3A).

Four pairs of long branchiae on chaetigers 2-5 (Figs 3A, C, D; 4A, B), first pair slightly longer than fourth, both with long, slender, dense digitiform pinnules on posterior stem faces and very long, naked, smooth distally pointed tips. Pairs 2 and 3 apinnate, shorter than pinnate pairs, but slightly longer than notopodial lamellae.

Notopodial postchaetal lamellae joining dorsally forming dorsal crests (Fig. 4B) from chaetigers 9 to 19, highest on chaetigers 10-11.

Anterior neuropodial prechaetal lamellae connected through poor-developed ventral crests from chaetigers 9 to 14, forming central U-shaped short depressions (Fig. 4D); subsequent chaetigers without ventral crests.

Neuropodial sabre chaetae from chaetiger 10, one per fascicle, stout, distinctly curved, basally smooth, heavily granulated medially and distally, with sheaths. Neuropodial hooded hooks from chaetiger 15 , up to 10 per fascicle. Hooks with five pairs of small teeth above large main tooth, and short, small secondary hoods (Fig. 4E).

Pygidium with two short bulbous cirri (Figs. 3B, 4F).

Methyl green staining pattern. Peristomium and posterior dorsal part of prostomium deeply stained, as notopodial lamellae of chaetigers 1-5 and neuropodial lamellae of chaetiger 1, anterior part of caruncle and posterior part of prostomium pigmented (Fig. 3C, D). 

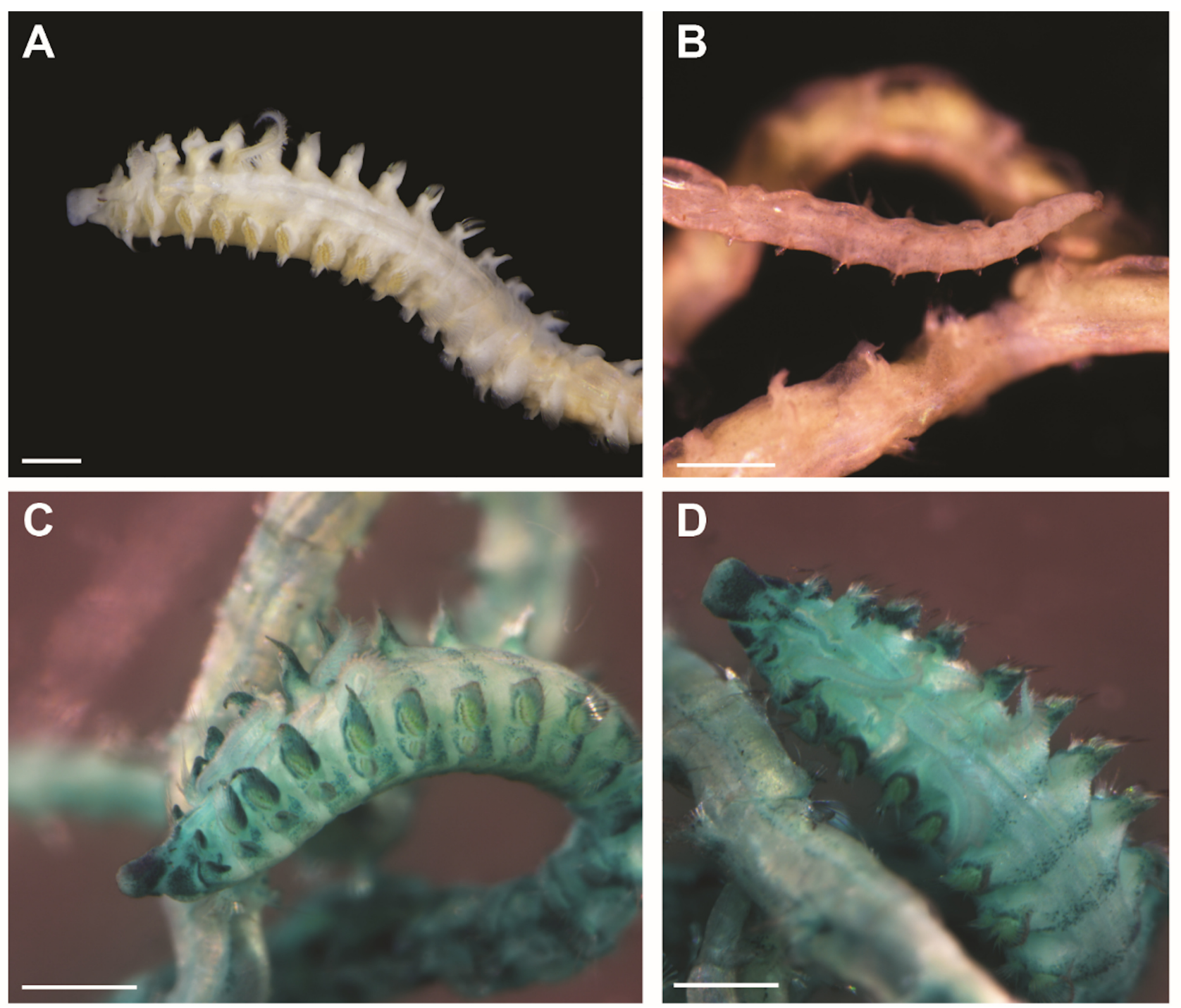

FIGURE 3. Prionospio cristaventralis, MNHN-IA-PNT-113. A. Anterior part; B. Pygidium; C. Anterior part, lateral view (Methyl green staining applied); D. Anterior part, dorsal view (Methyl green staining applied). Scales A-D=0.5 mm.

Remarks. The specimens of $P$. cristaventalis from French coast mostly fit in the type description but present a few variations: neuropodial postchaetal lamellae on chaetiger 1 slightly larger than notopodial one (much larger in Spanish specimens), notopodial postchaetal lamellae with pointed tips on chaetigers on chaetigers 2-5 (2-3 in Spanish specimens), dorsal crest begins on chaetiger 9 (10 in Spanish specimens), ventral crest poorly developed (well-developed in Spanish specimens), and sheath on sabre chaetae (absent in Spanish specimens).

Habitat. Shallow waters from 24 to 34 m (Delgado-Blas et al., 2018), in fine to coarse sand from 20 to 60 m (this study).

Distribution. Atlantic Ocean. Cantabrian Sea, Asturias, Spain (Delgado-Blas et al., 2018), Aquitanian coast, Bay of Biscay, France (this study, Fig. 1).

\section{Discussion}

Prionospio cristaventralis was recently described from museum specimens collected in the South Bay of Biscay in 1998 (Delgado-Blas et al. 2018) and there is no other information on its geographic distribution to date. These specimens were initially identified as P. fallax Söderström, 1920 or P. caspersi Laubier, 1962 (DelgadoBlas et al. 2018). Accordingly, specimens of these two species from South Western Europe, especially in the Bay of Biscay, should be re-examined and specimens collected de novo will require careful identifications. The 
Spanish type locality and the Aquitanian coast are quite close to each other, but the benthic communities of the latter area are still poorly known. However, the seasonal fluctuations in water circulation south to the Bay of Biscay, with eastward drift in autumn/winter and westward drift in spring/summer (Charria et al. 2013) may lead to connectivity between northern Spanish and southwestern French coasts, suggesting that the species may be naturally present on the Aquitanian coast.
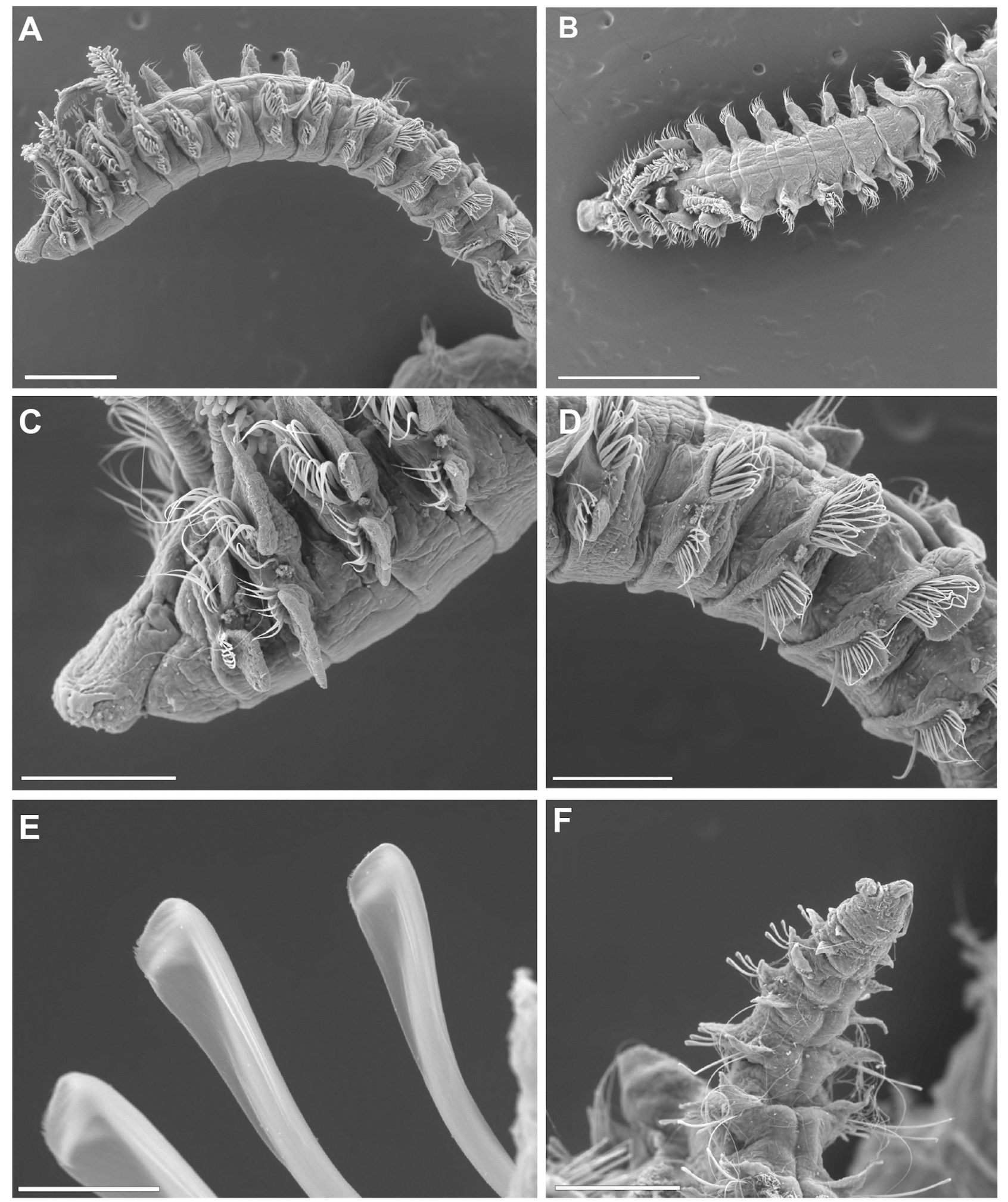

FIGURE 4. Prionospio cristaventralis SEM, MNHN-IA-PNT-114. A. Anterior region, lateral view B. Anterior region, dorsal view; C. Anterior region, lateral view; D. Chaetigers 9 to 13, lateral view; E. Neuropodial hooded hooks from far posterior; F. Pygidium, dorsal view. Scales: A, C, $\mathrm{F}=500 \mu \mathrm{m}, \mathrm{B}=1 \mathrm{~mm}, \mathrm{C}=125 \mu \mathrm{m}, \mathrm{D}=250 \mu \mathrm{m}, \mathrm{E}=15 \mu \mathrm{m}$. 
Spiophanes afer was described from its type locality in the Mediterranean Sea near Valencia, but additional records from various localities around the African continent outlined a rather large distribution range (e.g. off Israel, Mozambique, South Africa, Namibia, and Angola) (Meißner 2005; Gil 2011; Moritz 2012). In the Mediterranean the species was reported from the Spanish coast (Meißner 2005; same records confirmed by Delgado-Blas et al. 2019), the Adriatic Sea (Mikac 2015), the Aegean Sea off Turkey (Dagli et al. 2011; Çinar et al. 2014), and Israel (Meißner 2005). Some specimens in our local collection (initially misidentified as $S$. viriosus) were collected off Banyuls-sur-Mer in 2010, and thus represent the first confirmed occurrence of S. afer on the French Mediterranean coast. The northern-most records in the Atlantic came from Portugal, off Sines (1980s, Gil 2011) and from off Aveiro (1995-1996, Ravara \& Moreira 2013). Considering this, our recent sample of $S$. afer from Pertuis d'Antioche makes it the northern-most record from the NE Atlantic. Moreover, its arrival in the area seems recent since the only Spiophanes species known from there to date was $S$. bombyx (de Montaudouin \& Sauriau 2000). This latter species has a very different morphology and is unlikely to be confused with $S$. afer.

Also, it has been suggested that most records of $S$. kroyeri from the Western Mediterranean, including the Adriatic, and South European Atlantic refer to S. afer (Gil 2011; Mikac 2014). Spiophanes kroyeri, being an Arctic species, is unlikely to occur in Southern Europe (Meißner 2005). In French marine waters, S. kroyeri has been reported from the Bay of Biscay in the Atlantic (Glémarec 1969; Amoureux 1971; Lagardère 1972) and from Cerbère to Saint Raphael (RESOMAR 2019) in the Mediterranean. However, some specimens of Spiophanes from the Bay of Biscay (not S. bombyx) show "0+1 type" chaetal spreaders on chaetigers 5-7 and lack pigmentation on chaetigers 9-13. Despite resembling S. kroyeri, we suggest they more likely belong to a different, undescribed species (Jourde and Lavesque, unpublished data). Spiophanes duplex, described from Southern California, was also reported from the French Mediterranean during 1969-1972 and then in 2009, together with S. viriosus (OBIS, 2019; RESOMAR, 2019) and has not been recorded since then. In 2012, S. afer was reported between Italy and Spain, including Corsica (OBIS 2019), suggesting that the previous reports of Spiophanes in the Mediterranean Sea may also refer to this species. Therefore, despite the fact that we are reporting $S$. afer as present on the French Mediterranean coast at least since 2010, the literature and databases strongly suggest that it has been present in the area for a longer period of time.

In summary, the present state of knowledge on the spatio-temporal distribution of the species of Spiophanes, and particularly $S$. afer, does not allow an assessment of its real distribution in Europe. Further investigations will require that museum and private collections be checked, and new morphological and molecular analyses on fresh material (or preserved in a compatible way for DNA extraction) be carried out. In particular, acquisition of DNA sequences of $S$. afer from its type locality is needed to clarify the status of $S$. adriaticus.

\section{Acknowledgments}

The authors would like to thank those involved in sampling campaigns on board the RV "Côtes de la Manche" (JERICO-Next-H2020 and VOG CNRS LEFE-EC2CO programs, Bruno Deflandre, SGC CDM Fred (2016) JERICOBENT, https://doi.org/10.18142/284), RV "L'Estran" (La Rochelle Université) and "JIF Surveyor" (Jifmar Offshore Services, Bayonne), RV “Tethys II" (REDIT 2010, http://dx.doi.org/10.17600/10450130) funded by "Agence de l'Eau Corse-Méditerranée" (convention n²010 0871) and the "Agence des Aires Marines Protégées" (Marché N 2009-AAMP-16; Lot N9; ASCONIT/GIS Posidonie), and RV "Nereis II" (RNMCB funded by Conseil Départemental des Pyrénées Orientales and IBIS). We thank Tarik Meziane (MNHN Paris) for providing accession numbers in the difficult context of Covid-19 confinement. We are grateful to Pauline Cajéri, Jérôme Davignon and Jean-Damien Bergeron (CREOCEAN), Etienne Serres, Damien Saffroy and Aude Laurens (RTE) who kindly gave us worms collected in the southern Bay of Biscay, and to Fabien Aubert (Cohabys/ADERA) for his help on figure preparation. We are also grateful to the editor handling our manuscript and to Daniel Martin and an anonymous reviewer, who helped to improve an earlier version of the manuscript. 


\section{References}

Aguirrezabalaga, F. \& Ceberio, A. (2005) Spionidae (Polychaeta) from the Capbreton Canyon (Bay of Biscay, NE Atlantic) with description of a new genus and three new species. Marine Biology Research, 1, 267-280. https://doi.org/10.1080/17451000500262066

Amoureux, L. (1971) Annélides Polychètes capturés au large de la côte d'Arcachon. Inventaire taxonomique. Bulletin de la Société Linnéenne de Bordeaux, 1, 147-164.

Augener, H. (1918) Polychaeta. Beitrage zur Kenntnis der Meeresfauna Westafrikas, 2 (2), 67-625.

Blake, J.A., Maciolek, N.J. \& Meißner, K. (2017) Spionidae Grube, 1850. A Natural History of the Phyla of the Animal Kingdom, Annelida: Polychaeta. A. Schmidt-Rhaesa. Berlin, Boston: De Gruyter, pp. 1-109.

Berkeley, E. (1927) Polychaetous annelids from the Nanaimo district. Part 3. Leodicidae to Spionidae. Contributions to Canadian Biology and Fisheries, 3 (17), 407-422. https://doi.org/10.1139/f26-017

Bogantes, V.E., Halanych, K.M. \& Meißner, K. (2018) Diversity and phylogenetic relationships of North Atlantic Laonice Malmgren, 1867 (Spionidae, Annelida) including the description of a novel species. Marine Biodiversity, 48, 737-749. https://doi.org/10.1007/s12526-018-0859-8

Chamberlin, R.V. (1919) New polychaetous annelids from Laguna Beach, California. Pomona College Journal of Entomology and Zoology, 11 (1), 1-23.

Charria, G., Lazure, P., Le Cann, B., Serpette, A., Reverdin, G., Louazel, S., Batifoulier, F., Dumas, F., Pichon, A. \& Morel, Y. (2013) Surface layer circulation derived from Lagrangian drifters in the Bay of Biscay. Journal of Marine Systems, 109-110, Supplement, 60-76. https://doi.org/10.1016/j.jmarsys.2011.09.015

Çinar, M.E., Dağli, E. \& Şahin, G.K. (2014) Checklist of Annelida from the coasts of Turkey. Turkish Journal of Zoology, 38, 734-764. https://doi.org/10.3906/zoo-1405-72

Çinar, M.E., Dağli, E., Çağlar, S. \& Albayrak, S. (2015) Polychaetes from the northern part of the Sea of Marmara with the description of a new species of Polydora (Annelida: Polychaeta: Spionidae). Mediterranean Marine Science, 16 (3), 524-532. https://doi.org/10.12681/mms.1226

Claparède, E. (1870) Les Annélides Chétopodes du Golfe de Naples. Supplément. Mémoires de la Société de physique et d'histoire naturelle de Genève, 20 (2), 365-542.

D’Alessandro, M., Castriota, L., Maggio, T., Nasi, F., Carletti, M., Auriemma, R., Romeo, T. \& Del Negro, P. (2019) Spiophanes adriaticus, a new species from the Mediterranean Sea. Journal of the Marine Biological Association of the United Kingdom $100,45-54$. https://doi.org/10.1017/S0025315419001061

Day, J.H. (1961) The Polychaete Fauna of South Africa. Part 6. Sedentary species dredged off Cape coasts with a few new records from the shore. Journal of the Linnean Society of London, 44 (299), 463-560. https://doi.org/10.1111/j.1096-3642.1961.tb01623.x

Dagli, E., Cinar, M.E. \& Ergen Z. (2011) Spionidae (Annelida: Polychaeta) from the Aegean Sea (eastern Mediterranean). Italian Journal of Zoology 78, 49-64. https://doi.org/10.1080/11250003.2011.567828

Deflandre, B. (2016) JERICOBENT.

de Montaudouin, X. \& Sauriau, P.-G. (2000) Contribution to a synopsis of marine species richness in the Pertuis Charentais Sea with new insights in soft-bottom macrofauna of the Marennes-Oléron Bay. Cahiers de Biologie Marine, 41 (2), $181-222$.

Delgado-Blas, V.H., Díaz-Díaz, O. \& Viéitez J.M. (2018) Prionospio from the coast of the Iberian Peninsula, with the description of two new species (Annelida, Spionidae). ZooKeys, 810, 1-18. https://doi.org/10.3897/zookeys.810.26910

Delgado-Blas, V.H., Díaz-Díaz, O. \& Viéitez J.M. (2019) On the diversity of the genus Spiophanes Grube, 1860(Annelida: Spionidae) in the Spanish peninsular coast, with descriptions of two new species. Cahiers de Biologie Marine, 60, $335-351$.

Fauvel, P. (1928) Annélides polychètes nouvelles du Maroc. Bulletin de la Société Zoologique de France, 53 (1), 9-13.

Gil, J. (2011) The European fauna of Annelida Polychaeta. Unpublished PhD Thesis, Universidade de Lisboa, Lisbon, 1554 pp.

Glémarec, M. (1969) Les peuplements benthiques du plateau continental Nord-Gascogne. Thèse de Doctorat d'Etat es Sciences Naturelles. Université de Paris VI, Paris, 167 pp.

Grube, A.E. (1860) Beschreibung neuer oder wenig bekannter Anneliden. Fünfter Beitrag. Archiv für Naturgeschichte, Berlin. $26(1), 71-118$. https://doi.org/10.5962/bhl.title.11291

Lagardère, F. (1972) Les fonds de pêche de la côte ouest de l'île d'Oléron. Cartographie bionomique. III-Les peuplements benthiques. Tethys, 3 (3), 507-538.

Laubier, L. (1962) Quelques Annélides Polychètes de la Lagune de Venise description de Prionospio caspersi n. sp. Vie et Milieu, 13 (1), 123-159.

Laubier, L. (1964) Un Spionidien des vases bathyales de Banyuls-sur-Mer, Spiophanes kroyeri reyssi ssp. n. Bulletin de la 
Société Zoologique de France, 89 (4), 562-577.

Lavesque, N., Bonifácio, P., Meißner, K., Blanchet, H., Gouillieux, B., Dubois, S. \& Bachelet, G. (2015) New records of Spio symphyta and Spio martinensis ('Polychaeta': Canalipalpata: Spionidae) from Arcachon Bay (France), NE Atlantic. Marine Biodiversity, 45 (1), 77-86. https://doi.org/10.1007/s12526-014-0230-7

Liénart, C., Savoye, N., Bozec, Y., Breton, E., Conan, P., David, V., Feunteun, E., Grangeré, K., Kerhervé, P., Lebreton, B., Lefebvre, S., L'Helguen, S., Mousseau, L., Raimbault, P., Richard, P., Riera, P., Sauriau, P.-G., Schaal, G., Aubert, F., Aubin, S., Bichon, S., Boinet, C., Bourasseau, L., Bréret, M., Caparros, J., Cariou, T., Charlier, K., Claquin, P., Cornille, V., Corre, A.-M., Costes, L., Crispi, O., Crouvoisier, M., Czamanski, M., Del Amo, Y., Derriennic, H., Dindinaud, F., Durozier, M., Hanquiez, V., Nowaczyk, A., Devesa, J., Ferreira, S., Fornier, M., Garcia, F., Garcia, N., Geslin, S., Grossteffan, E., Gueux, A., Guillaudeau, J., Guillou, G., Joly, O., Lachaussée, N., Lafont, M., Lamoureux, J., Lecuyer, E., Lehodey, J.-P., Lemeille, D., Leroux, C., Macé, E., Maria, E., Pineau, P., Petit, F., Pujo-Pay, M., Rimelin-Maury, P. \& Sultan, E. (2017) Dynamics of particulate organic matter composition in coastal systems: A spatio-temporal study at multi-systems scale. Progress in Oceanography, 156, 221-239. https://doi.org/10.1016/j.pocean.2017.03.001

Malmgren, A.J. (1867) Annulata Polychaeta Spetsbergice, Groenlandice, Islandice et Scandinavice. Hactenus Cognita. Ex Officina Frenckelliana, Helsingforslæ, $127 \mathrm{pp}$. https://doi.org/10.5962/bhl.title.13358

Massé, C., Meisterhans, G., Deflandre, B., Bachelet, G., Bourasseau, L., Bichon, S., Ciutat, A., Jude-Lemeilleur, F., Lavesque, N., Raymond, N., Grémare, A. \& Garabetian, F. (2016) Bacterial and macrofaunal communities in the sediments of the West Gironde Mud Patch, Bay of Biscay (France). Estuarine, Coastal and Shelf Science, 179, 189-200. https://doi.org/10.1016/j.ecss.2016.01.011

Martínez, J. \& Adarraga, I. (2019) First records of two species of Spionidae (Annelida) from Bay of Biscay and European coasts. Cahiers de Biologie Marine, 60, 369-379.

Meißner, K. (2005) Revision of the genus Spiophanes (Polychaeta, Spionidae); with new synonymies, new records and descriptions of new species. Mitteilungen aus dem Museum für Naturkunde in Berlin, Zoologische Reihe, 81 (1), 3-66. https://doi.org/10.1002/mmnz.200310001

Meißner, K. \& Hutchings, P.A. (2003) Spiophanes species (polychaeta: Spionidae) from eastern Australia: with descriptions of new species, new records and an emended generic diagnosis. Records of the Australian Museum, 55 (2), 117-140. https://doi.org/10.3853/j.0067-1975.55.2003.1379

Meißner, K., Bick, A., Guggolz, T. \& Götting, M. (2014) Spionidae (Polychaeta: Canalipalpata: Spionida) from seamounts in the NE Atlantic. Zootaxa, 3786 (3), 201-245. https://doi.org/10.11646/zootaxa.3786.3.1

Mikac, B. (2015) A sea of worms: polychaete checklist of the Adriatic Sea. Zootaxa, 3943 (1), 1-172. https://doi.org/10.11646/zootaxa.3943.1.1

Moritz, D. (2012) Composition and distribution of the macrozoobenthic communities on the shelf off Angola. Master Thesis Marine Biology, University of Rostock, 49 pp.

OBIS (2019) Ocean Biogeographic Information System. Intergovernmental Oceanographic Commission of UNESCO. Available from: www.iobis.org (accessed 18 September 2019)

Radashevsky, V.I., Pankova, V.V., Neretina, T.V., Stupnikova, A.N. \& Tzetlin, A.B. (2016) Molecular analysis of the Pygospio elegans group of species (Annelida: Spionidae). Zootaxa, 4083 (2), 239-250. https://doi.org/10.11646/zootaxa.4083.2.4

Radashevsky, V.I., Pankova, V.V., Malyar, V.V., Neretina, T.V., Wilson, R.S., Worsfold, T.M., Diez, M., Harris, L., Hourdez, S., Labrune, C., Houbin, C., Kind, B., Kuhlenkamp, R., Nygren, A., Bonifacio, P. \& Bachelet, G. (2019) Molecular analysis and new records of the invasive polychaete Boccardia proboscidea (Annelida: Spionidae). Mediterranean Marine Science, 20 (2), 393-408.

https://doi.org/10.12681/mms.20363

Ravara, A. \& Moreira M.H. (2013) Polychaeta (Annelida) from the continental shelf off Aveiro (NW Portugal): Species composition and community structure. Check List, 9 (3), 533-539. https://doi.org/10.15560/9.3.533

Read, G. \& Fauchald, K. (Ed.) (2019) World Polychaeta database. Spionidae Grube, 1850. Available from: http://marinespecies. org/aphia.php?p=taxdetails\&id=913 (accessed 2 September 2019)

RESOMAR (2019) French marine stations and observatories network Database. Available from: http://resomar.cnrs.fr/bases/ index.php (accessed 18 September 2019)

Söderström, A. (1920) Studien über die Polychätenfamilie Spionidae. Uppsala University, pp. 1-286.

Surugiu, V. (2016) On the taxonomic status of the European Scolelepis (Scolelepis) squamata (Polychaeta: Spionidae), with description of a new species from southern Europe. Zootaxa, 4161 (2), 151-176. https://doi.org/10.11646/zootaxa.4161.2.1

Wirén, A. (1883) Chaetopoder från Sibiriska Ishafvet och Berings Haf Insamlade under Vega-Expeditionen 1878-1879. VegaExpeditionens Vetenskapliga Iakttagelser bearbetade af deltagare i resan och andra forskare: Stockholm, F\&G Beijers Förlag, 2, 383-428. 